\title{
The development and validation of HPLC-DMD method for intermediate products impurities determination of morpholinium 2-((4-(2-methoxyphenyl)-5-(pyridine-4-yl)-4H-1,2,4-triazole-3-yl)thio)acetate in bulk drug
}

\author{
B. 0. Varynskyi, A. G. Kaplaushenko
}

Zaporizhzhia State Medical University, Ukraine

Purpose. A development and validation of new sensitive, high efficient and selective HPLC determination method of intermediates technological contaminations in bulk drug of morpholin-4-ium 2-((4-(2-methoxyphenyl)-5-(pyridine-4-yl)-4H-1,2,4-triazole-3-yl) thio)acetate (active pharmaceutical ingredient - API).

Materials and methods. LC System was Agilent 1260 Infinity (degasser, binary pump, autosampler, column thermostat, diode array detector) Open LAB CDS Software. Column was Zorbax SB-C18; $30 \mathrm{~mm} \times 4.6 \mathrm{~mm} ; 1.8 \mu \mathrm{m}$. Injection volume was $5 \mu \mathrm{L}$. Isocratic mode. The mobile phase was water/acetonitrile (84:16) with $0.1 \%$ methanoic acid. Standard samples were morpholinium 2-((4-(2-methoxyphenyl)-5-(pyridin-4-yl)-4H-1,2,4-triazol-3-yl)thio)acetate, pyridine-4-carbohydrazide, 2-isonicotinoyl- N-(2-methoxyphenyl)hydrazine-1-carbothioamide, 4-(2-methoxyphenyl)-5-(pyridin-4-yl)-2,4-dihydro-3H-1,2,4-triazole-3-thione.

Results. A new criterion for choosing chromatographic separation condition was proposed. It is absolute value of retention factors differences $(|\Delta k|)$. Six different curves which show dependence of absolute value of retention factors differences $(|\Delta k|)$ for each compound from the acetonitrile in mobile phase was built at registration of the signal on diode-array detector. A chromatographic separation optimal condition of impurities and API in drug bulk was found with satisfied resolution. UV spectra of API and impurities were determined. Method of the quantitative determination of the impurities was elaborated. Total sample preparation uncertainty was predicted. Method was validated according to European and Ukrainian Pharmacopeia. It was applied for real bulk drug samples.

Conclusions. Chromatography separation of impurities and API was done. A method was complied with linearity criteria, specificity, precision and accuracy. The results of impurity determination in bulk drug indicated, that method can be used for the quality control of bulk drug.

\section{Розробка та валідація ВЕРХ-АМА методики визначення домішок напівпродуктів морфоліній 2-((4-(2-метоксифенік)-5-(піридин-4-іл)-4Н-1,2,4-тріазол-3-іл)тіо)ацетату в субстанції}

\section{Б. О. Варинський, А. Г. Каплаушенко}

Мета роботи - розробка та валідація нового чутливого й селективного ВЕРХ-способу визначення проміжних технологічних домішок у субстанції з морфоліній 2-((4-(2-метоксифеніл)-5-(піридин-4-іл)-4H-1,2,4-тріазол-3-іл)тіо)ацетату (активний фармацевтичний інгредієнт - АФІ).

Матеріали та методи. LC Система була Agilent 1260 Infinity (дегазатор, бінарний насос, автосамплер, термостат колонки, діодно-матричний детектор), програмне забезпечення Open LAB CDS. Колонка Zorbax SB-C18; 30 мм×4,6 мм; 1,8 мкм. Обсяг інжекції становив 5 мкл. Ізократичний режим. Рухома фаза вода/ацетонітрил (84:16) з 0,1\% метанової кислоти. Стандартні зразки - морфоліній 2-((4-(2-метоксифеніл)-5-(піридин-4-іл)-4Н-1,2,4-тріазол-3-іл)тіо)ацетат, піридин-4-карбогідразід, 2-ізонікотиноїл-N-(2-метоксифеніл)-гідразин-1-карботіоамід, 4- (2-метоксифеніл)-5-(піридин-4-іл)-2,4-дигідро-3Н-1,2,4-триазол-3-тіон.

Результати. Запропонований новий критерій для вибору умов хроматографрічного розділення речовин. Це - абсолютне значення відмінності фракторів утримання $(|\Delta k|)$. Побудовано шість різних кривих, які показують залежність абсолютного значення різниць фракторів утримання $(|\Delta k|)$ для кожної сполуки від вмісту ацетонітрилу в рухомій фразі під час реєстрації сигналу на діодно-матричному детекторі. Оптимальні умови хроматографічного розділення домішок та АФІ в субстанції знайдені з задовільною роздільною здатністю. УФ-спектри АФІ та домішок визначені. Розроблений метод кількісного визначення домішок. Спрогнозована загальна невизначеність підготовки проб. Метод валідований відповідно до Європейської та Української фармакопеї. Він застосований для реальних зразків лікарської субстанції.

Висновки. Зроблено хроматографрічне розділення домішок та АФІ. Метод відповідає критеріям лінійності, специфічності, правильності, збіжності. Результати визначення домішок у субстанції лікарської речовини показують, що метод може бути використаний для контролю якості субстанції лікарської речовини.

\section{Разработка и валидация ВЭЖХ-АМА методики определения примесей полупродуктов морфолиний 2-((4-(2-метоксифенил)-5-(пиридин-4-ил)-4Н-1,2,4-триазол-3-ил)тио)ацетата в субстанции}

\section{Б. А. Варинский, А. Г. Каплаушенко}

Цель работы - разработка и валидация нового чувствительного и селективного ВЭЖХ-метода определения промежуточных технологических примесей в субстанции лекарственного вещества морфолиний 2-((4-(2-ме-
Key words: triazoles, high pressure liquid chromatography, pharmaceutical products, drug contamination

\section{Zaporozhye} medical journal 2017; 19 (3), 373-380 DOI: 10.14739/2310-1210 2017.3.100947

\section{E-mail:}

varinsky@zsmu.zp.ua

Кнючові слова: тріазоли, високоефективна рідинна хроматографія, фармацевтичн продукти, Аомішки у субстанцію мікарської речовини.

Запорізький медичний журнал. - 2017. T. 19, № 3(102). C. $373-380$ 
Запорожский медицинский журнал. - 2017. -

T. 19, № 3(102). C. $373-380$

токсифенил)-5-(пиридин-4-ил)-4Н-1,2,4-триазол-3-ил)тио)ацетата (активный фармацевтический ингредиент АФИ).

Материалы и методы. LC система была Agilent 1260 Infinity (дегазатор, бинарный насос, автосамплер, колоночный термостат, диодно-матричный детектор). Программное обеспечение Open LAB CDS. Колонка Zorbax SB-C18; 30 мм × 4,6 мм; 1,8 мкм. Инжектируемый объём составлял 5 мкл. Изократический режим. Подвижной фазой является вода/ацетонитрил $(84: 16)$ с 0,1 \% метановой кислотой. Стандартными образцами были морфолиний 2-((4-(2-метоксифенил)-5-(пиридин-4ил)-4H-1,2,4-триазол-3-ил)тио)ацетат, пиридин-4-карбогидразид, 2-изоникотиноил-N-(2-метоксифенил)-гидразин-1-карботиоамид, 4-(2-метоксифенил)-5-(пиридин-4-ил)-2,4-дигидро-3Н-1,2,4-триазол-3-тион.

Результаты. Предложен новый критерий выбора условий разделения. Это - абсолютное значение разности коэффициентов удерживания $(|\Delta k|)$. При регистрации сигнала на диодно-матричном детекторе построено шесть различных кривых, которые показывают зависимость абсолютной величины разностей коэффициентов удерживания (| $\Delta k \mid)$ для каждого соединения от содержания ацетонитрила в подвижной фазе. Оптимизировано хроматографическое разделение примесей АФИ в субстанции лекарственного вещества с удовлетворительной разделяющей способностью. Определены УФ-спектры АФИ и примесей. Разработан метод количественного определения примесей. Спрогнозирована общая неопределённость пробоподготовки. Метод был подтверждён в соответствии с Европейской и Украинской фрармакопеей. Он был применён для реальных образцов субстанции лекарственных веществ.

Выводы. Выполнено хроматографическое разделение примесей и АФИ. Метод соответствовал критериям линейности, специфичности, правильности и сходимости. Результаты определения примесей в субстанции лекарственного вещества показали, что этот метод может быть использован для контроля качества лекарственного средства в субстанции.

\section{Introduction}

Heterocyclic systems which are based on 1,2,4-triazole are interesting for modern pharmaceutical chemistry [1]. They have antioxidant, hepatoprotective and other activities, in addition some of them are already registered and are used in the practice. The morpholinium 2-((4-(2-methoxyphenyl)5-(pyridine-4-yl)-4H-1,2,4-triazole-3-yl)thio)acetate is active pharmaceutical ingredient (API) of new drug. It is under registration and introduction to industry. That's why the development of determination methods for its impurities, which effect on its pharmacological properties is an important task of modern pharmaceutical science, it has interest and practical significance.

Nowadays we know quantitative determination method of studied API and impurities in bulk drug with high performance liquid chromatography (HPLC). Method based on $5 \mu \mathrm{m}$ sorbent. It has low efficiency and selectivity. It considers only single impurity, has low sensitivity and time-consumable. Spectrophotometric method of determination it API in 1 and $2.5 \%$ water solutions doesn 't allow to determine the impurities [2].

The most effective method of impurity determination in pharmaceutical preparations and bulk drugs is HPLC with $1.8 \mu \mathrm{m}$ size of sorbent particles.

\section{The purpose of the work}

The purpose of this research is the development and validation of new sensitive, high efficient, selective HPLC determination method of intermediates technological contaminations in bulk drug of morpholinium 2-((4-(2-methoxyphenyl)-5-(pyridine-4-yl)-4H-1,2,4-triazole-3-yl)thio) acetate.

\section{Materials and methods}

The study was conducted by high performance liquid chromatography with diode-array detection for determination of the pyridine-4-carbohydrazide (2), 2-isonicotinoyl- $N$-(2-methoxyphenyl)hydrazine-1-carbothioamide (3),
4-(2-methoxyphenyl)-5-(pyridin-4-yl)-2,4-dihydro-3H-1,2,4triazole-3-thione (4).

HPLC Device. Agilent 1260 Infinity (degasser, binary pump, autosampler, column thermostat, diode array detector) OpenLAB CDS Software. Column Zorbax SB-C18; $30 \mathrm{~mm} \times 4.6 \mathrm{~mm} ; 1.8 \mu \mathrm{m}$. Quadrupole LC/MS 6120.

Reagents. Acetonitrile qualified "HPLC" LAB-SCAN (Gliwice, Poland), methanoic acid (100\%) Merck KGaA (Darmstadt, Germany), highly purified water (18 $\mathrm{M} \Omega$ the temperature $25^{\circ} \mathrm{C}$ ), that is prepared using Direct $\mathrm{Q} 3 \mathrm{UV}$ Millipore (Molsheim, France).

Standard samples. Morpholinium 2-((4-(2-methoxyphenyl)-5-(pyridin-4-yl)-4H-1,2,4-triazol-3-yl)thio)acetate (API) (1), pyridine-4-carbohydrazide (2), 2-isonicotinoyl$\mathrm{N}$-(2-methoxyphenyl)hydrazine-1-carbothioamide (3), 4-(2-methoxyphenyl)-5-(pyridin-4-yl)-2,4-dihydro-3H-1,2,4triazole-3-thione (4).

Chromatographic condition.

- column is $\varnothing 4.6 \times 30 \mathrm{~mm}$, reverse phase C18, $1.8 \mu \mathrm{m}$;

- column temperature is $40^{\circ} \mathrm{C}$;

- mobile phase $\mathrm{A}$ is $\mathrm{H}_{2} \mathrm{O}-0.1 \% \mathrm{HCOOH}$;

- mobile phase $\mathrm{B}$ is $\mathrm{CH}_{3} \mathrm{CN}-0.1 \% \mathrm{HCOOH}$;

- flow is $400 \mu \mathrm{L} / \mathrm{min}$;

- isocratic mode is mobile phase $A$ - mobile phase $B$ (84:16);

- injection volume is $5 \mu \mathrm{L}$;

- detector is diode-array (at $272 \mathrm{~nm}$ (compound (1)), at $266 \mathrm{~nm}$ (compound (2)), at $254 \mathrm{~nm}$ (compound (3)), at $258 \mathrm{~nm}$ (compound (4));

- chromatography time is 6 min.

System suitability. Column efficiency $N$ at peak API should be $\geq 4500$ of theoretical plates, at peak (2) $\geq 500$, at peak (3) $\geq 4700$, at peak (4) $\geq 3500$ resolution should be $R \geq 2.96$ (between API peaks and compound 3 ) and $R \geq 2.65$ (between peaks of compound 4 and API).

Preparation of the mobile phase $A .1 .00 \mathrm{~mL}$ of methanoic acid was added to volumetric flask with capacity $1000.0 \mathrm{~mL}$, dissolved in $100.0 \mathrm{~mL}$ of highly purified water. The volume of solution was brought to mark by using the same solvent and mixed. 
Preparation of the mobile phase $B .1 .00 \mathrm{~mL}$ of methanoic acid was added to volumetric flask with capacity $1000.0 \mathrm{~mL}$, dissolved in $100.0 \mathrm{~mL}$ of acetonitrile, the volume of solution was brought to mark by using the same solvent and mixed.

Preparation of solutions of standard samples. The standard samples (25.0 mg of pyridine-4-carbohydrazide, 2-isonicotinoyl- $N$-(2-methoxyphenyl)hydrazine-1-carbothioamide and 4-(2-methoxyphenyl)-5-(pyridine-4-yl)-2,4dihydro-3H-1,2,4-triazole-3-thione) were added to volumetric flask with capacity $100.0 \mathrm{~mL}$, added $50 \mathrm{~mL}$ of dimethyl sulfoxide. The volume of solution was brought to mark by using the same solvent and carefully mixed (solution IA). $1.00 \mathrm{~mL}$ of received solution was added to volumetric flask with capacity $100.0 \mathrm{~mL}$, brought the volume of solution to mark by highly-purified water and acetonitrile (84:16) and carefully mixed (solution IB).

Preparation of soluition for chromatography system suitability test. A weight of morpholinium 2-((4-(2-methoxyphenyl)-5-pyridine-4-yl)-4H-1,2,4-triazole-3-yl)thio)acetate standard sample $(250.0 \mathrm{mg}$ ) was weighed accurately and transferred to volumetric flask with capacity $100.0 \mathrm{~mL}$, dissolved in the highly-purified water and acetonitrile (84:16). $1.00 \mathrm{~mL}$ of the solution IA was added to it flask. The volume of solution was brought to mark by using the same solvent and carefully mixed.

Preparation of the test solution. An aliquot of $250.0 \mathrm{mg}$ of the bulk drug sample was added to volumetric flask with capacity $100.0 \mathrm{~mL}$ then, dissolved in the $50.0 \mathrm{~mL}$ compound of highly-purified water and acetonitrile (84:16), brought the volume of solution to mark by the same solvent and carefully mixed.

Solutions of 2,3,4 standard samples are chromatographed, RSD is counted for each sample area, chromatography is stopped, when received values of RSD do not exceed the value $R S D_{\max }$, which are calculated according to Ph. Eur. 2.2.46 and Ph. Ukr. 2.2.29. (The Supplement 1) for content limit of the compound (2) $B=16 \%$, content limits of the compound (3) and compound (4) is $B=5 \%[3,4]$.

The solution of standard samples 2, 3, 4 and investigated solution are alternately chromatographed with (n) times, average values are used in further calculations.

When it is chromatographed at mentioned conditions, the retention time of pick API should be about $4.6 \mathrm{~min}$, compound 2 (about $0.7 \mathrm{~min}$ ) compound 3 (about $3.9 \mathrm{~min}$ ) compound 4 (about $5.6 \mathrm{~min}$ ).

The content of pyridine-4-carbohydrazide, 2-isonicotinoyl- $N$-(2-methoxyphenyl)hydrazine-1-carbothioamide, 4-(2-methoxyphenyl)-5-(pyridin-4-yl)-2,4-dihydro-3H-1,2,4triazole-3-thione in bulk drug $\mathrm{X}, \%$, is determined by using the formula:

$$
X=\frac{S_{x} \times m_{s t} \times P}{S_{s t} \times m_{x} \times(100-W)},
$$

where $S_{x}$ - average value of the pick area pyridine-4-carbohydrazide, 2-isonicotinoyl-N-(2-methoxyphenyl) hydrazine-1-carbothioamide, 4-(2-methoxyphenyl)-5-(pyridin-4-yl)-2,4-dihydro-3H-1,2,4-triazole-3-thione for chromatograms of the test solution;

$S_{\mathrm{st}}$ - the average value of the area of pyridine-4-carbohydrazide, 2-isonicotinoyl- $N$-(2-methoxyphenyl) hydrazine-1-carbothioamide, 4-(2-methoxyphenyl)-5-(pyridin-4-yl)-2,4-dihydro-3H-1,2,4-triazole-3-thione for chromatograms of the standard working samples; $m_{\mathrm{st}}$ - weight of the pyridine-4-carbohydrazide, 2-isonicotinoyl- $N$-(2-methoxyphenyl)hydrazine-1-carbothioamide, 4-(2-methoxyphenyl)-5-(pyridin-4-yl)-2,4-dihydro-3H-1,2,4triazole-3-thione standard samples, g;

$m_{x}-$ weight of the investigated sample of bulk drug, $g$;

$P$ - the content of substance in the standard sample, \%;

$w$ - the content of the water in bulk drug, $\%$.

\section{Results and Discussion}

Interpretation of the method conditions.

The specific impurities of compound $(2,3,4)$ can get into bulk drug of API in process of synthesis [1]. These impurities are identified by chromatography with mass spectrometric detection. The picks of appropriate impurities are detected at appropriate SIM with $\mathrm{m} / \mathrm{z} 138,303,285$, they are also complied in retention time on appropriate standards (Fig. 1-3).

Chromatography determination conditions of these compounds should ensure them separation from API.

Optimization of concentration acetonitrile in the mobile phase.

Earlier we have discussed and suggested stationary phase and mobile phase, made an investigation of chromatographic behavior of a series of derivatives of 1,2,4-triazole and intermediate products of synthesis [5-7].

Based on received facts, we have built the graph of dependence of retention (capacity) factor $k$ from concentration of acetonitrile in mobile phase for potential impurities and

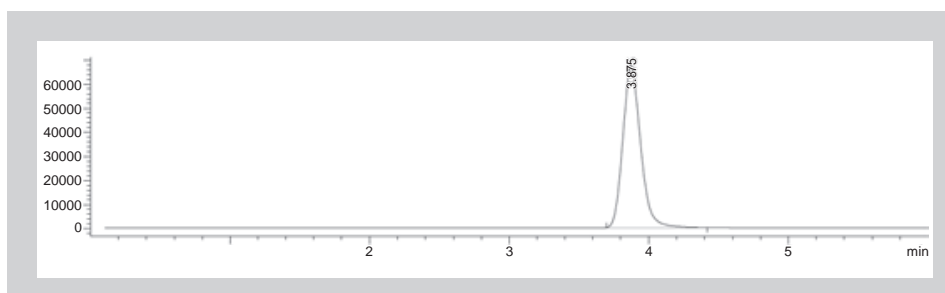

Fig. 1. The chromatogram of impurities model mixture $\mathrm{SIM} \mathrm{m} / \mathrm{z} 303$. The impurity of 2-isonicotinoyl$\mathrm{N}$-(2-methoxyphenyl)hydrazine-1-carbothioamide (retention time $3.875 \mathrm{~min}$ ).

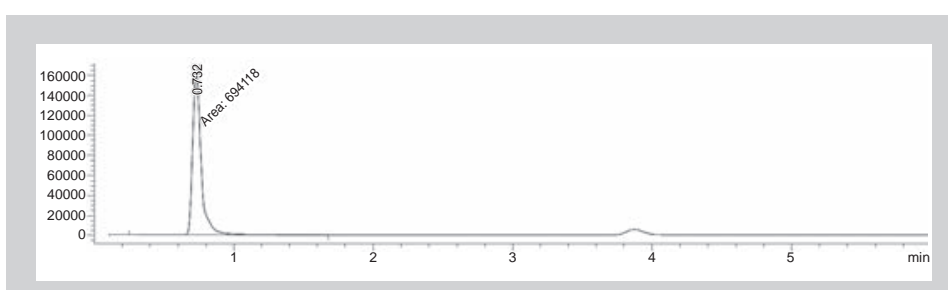

Fig. 2. The chromatogram of impurities model mixture SIM $\mathrm{m} / \mathrm{z}$ 138. The impurity of pyridine-4carbohydrazide (retention time $0.732 \mathrm{~min}$ ).

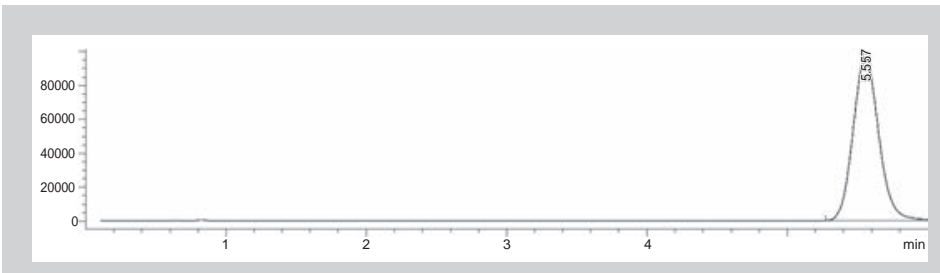

Fig. 3. The chromatogram of impurities model mixture SIM $\mathrm{m} / \mathrm{z} 285$. The impurity of 4-(2-methoxyphenyl)-5-(pyridin-4-yl)-2,4-dihydro-3H-1,2,4-triazole-3-thione (retention time 5.557 min). 


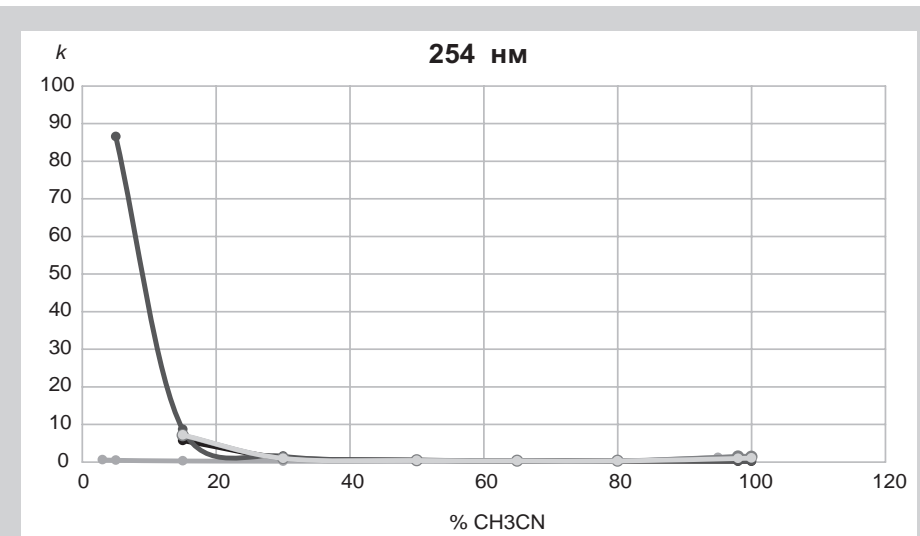

Fig. 4. Dependence of the retention factor $(k)$ from concentration of acetonitrile in mobile phase.

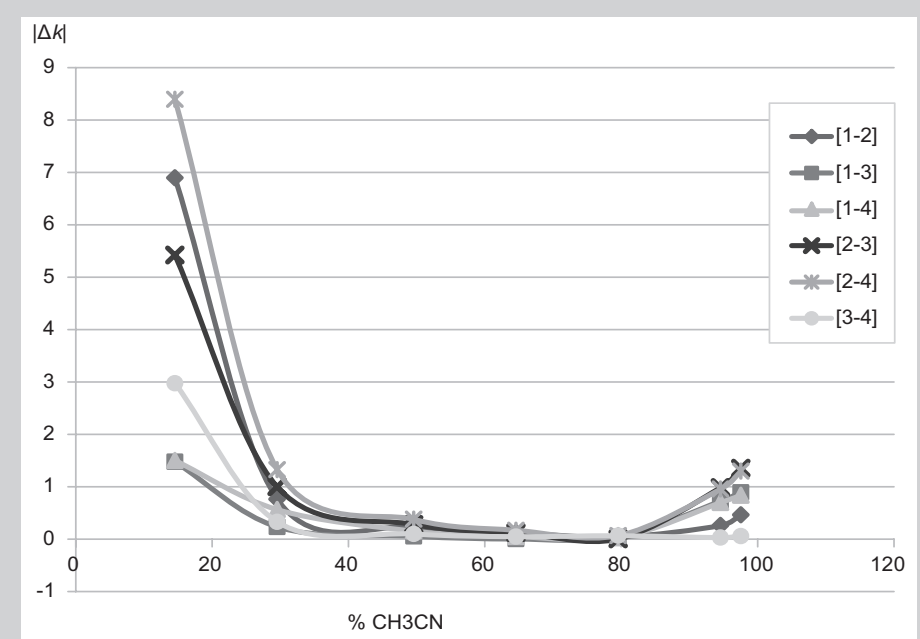

Fig. 5. Dependence of absolute value of retention factors differences for each compound from the acetonitrile in mobile phase.
API at registration of the signal on diode-array detector at wavelength $254 \mathrm{~nm}$ (Fig. 4).

On this graph we can see, that maximum difference between curves is about $16-18 \%$. Index, which shows the quality of separation is the resolution $\left(R_{s}\right)$. Experimental determination and calculation of the resolution $\left(R_{\mathrm{s}}\right)$ are conducted according to $\mathrm{Ph}$. Eur. and Ph. Ukr. with using Open LAB CDS Software $[3,4,8]$. The separation between picks of API (1) and carbotiamide (3), API (1) and thione (4) is most critical at this research. A dependence of resolution for most problematic separations (compounds 3-1 and 1-4) from concentration of acetonitrile in the eluent was studied. According to Ph. Ukr. the results are considered sufficient if the resolution is more than 1.0. All resolution values were over 1.0, but resolutions were maximal and standard deviations of both resolutions were minimal at the $16 \%$ (Table 1). Therefore, the optimal content of acetonitrile is $16 \%$.

Table 1. Dependence of the resolutions from acetonitrile content for compounds 3 and 1,1 and 4

\begin{tabular}{|c|c|c|c|}
\hline Indicator & $16 \%$ & $17 \%$ & $18 \%$ \\
\hline$R_{3,1}$ & 2.96 & 2.1 & 1.27 \\
\hline$R_{1,4}$ & 2.65 & 3.37 & 3.62 \\
\hline amount & 5.61 & 5.47 & 4.89 \\
\hline SD & 0.219 & 0.898 & 1.662 \\
\hline
\end{tabular}

Alternatively, we proposed new criteria for choosing of separation condition. It is retention factors differences $(|\Delta k|)$. Number of combinations for separation of two compounds for total number of four compounds are equal:

$$
C_{n}^{r}=\frac{n !}{r !(n-r) !}=\frac{4 !}{2 !(4-2) !}=6
$$

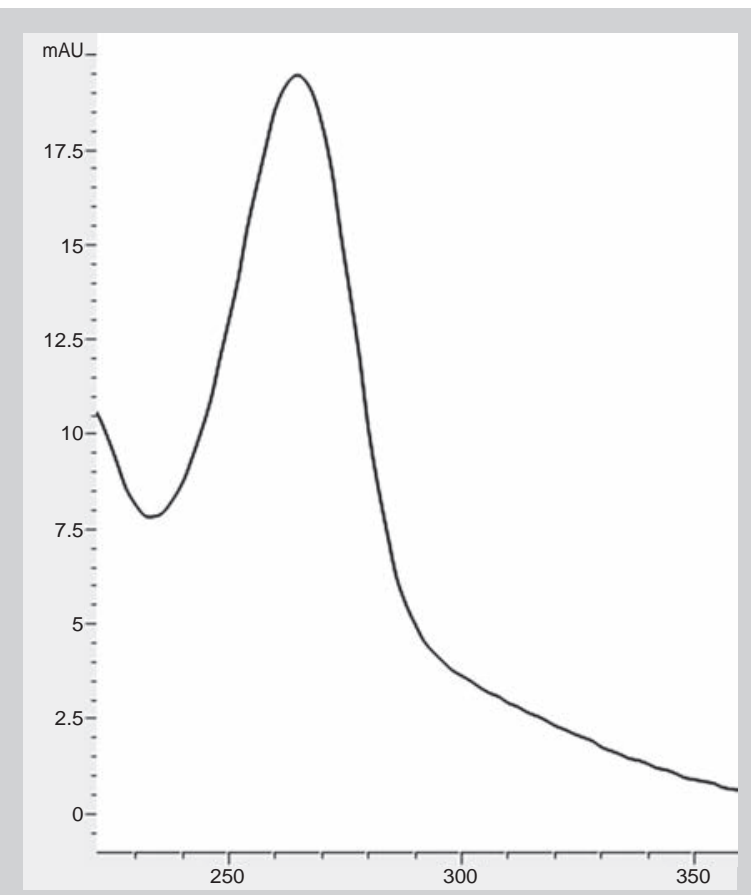

Fig. 6. UV spectra of pyridine-4-carbohydrazide.

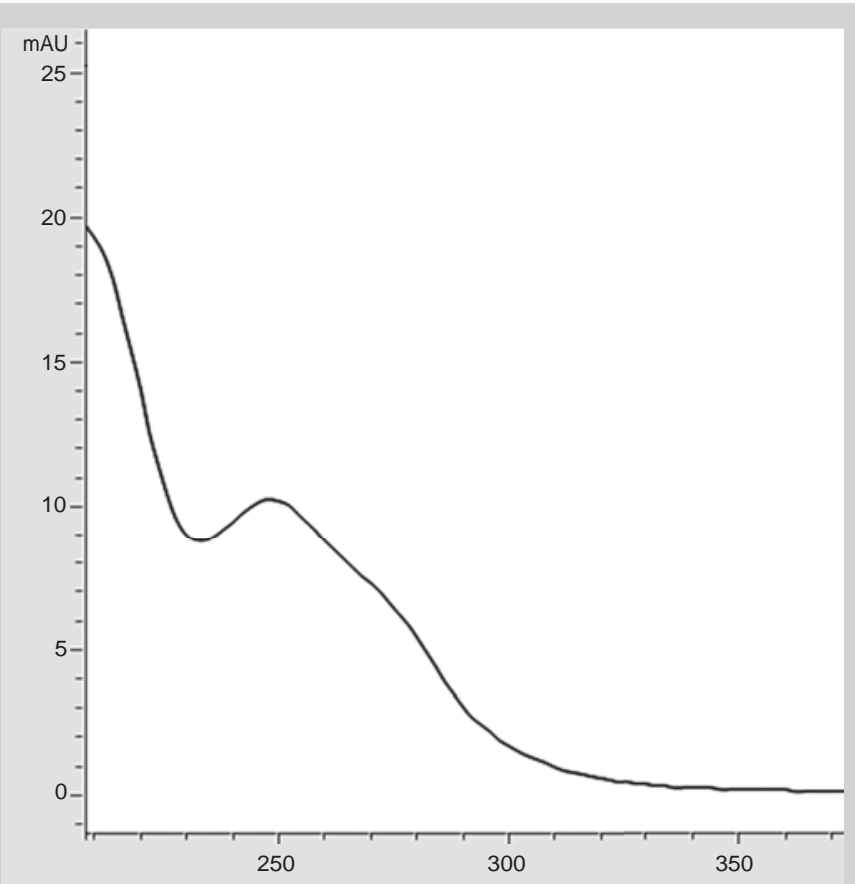

Fig. 7. UV spectra of 2-isonicotinoyl-N-(2-methoxyphenyl)hydrazine-1-carbothioamide. 


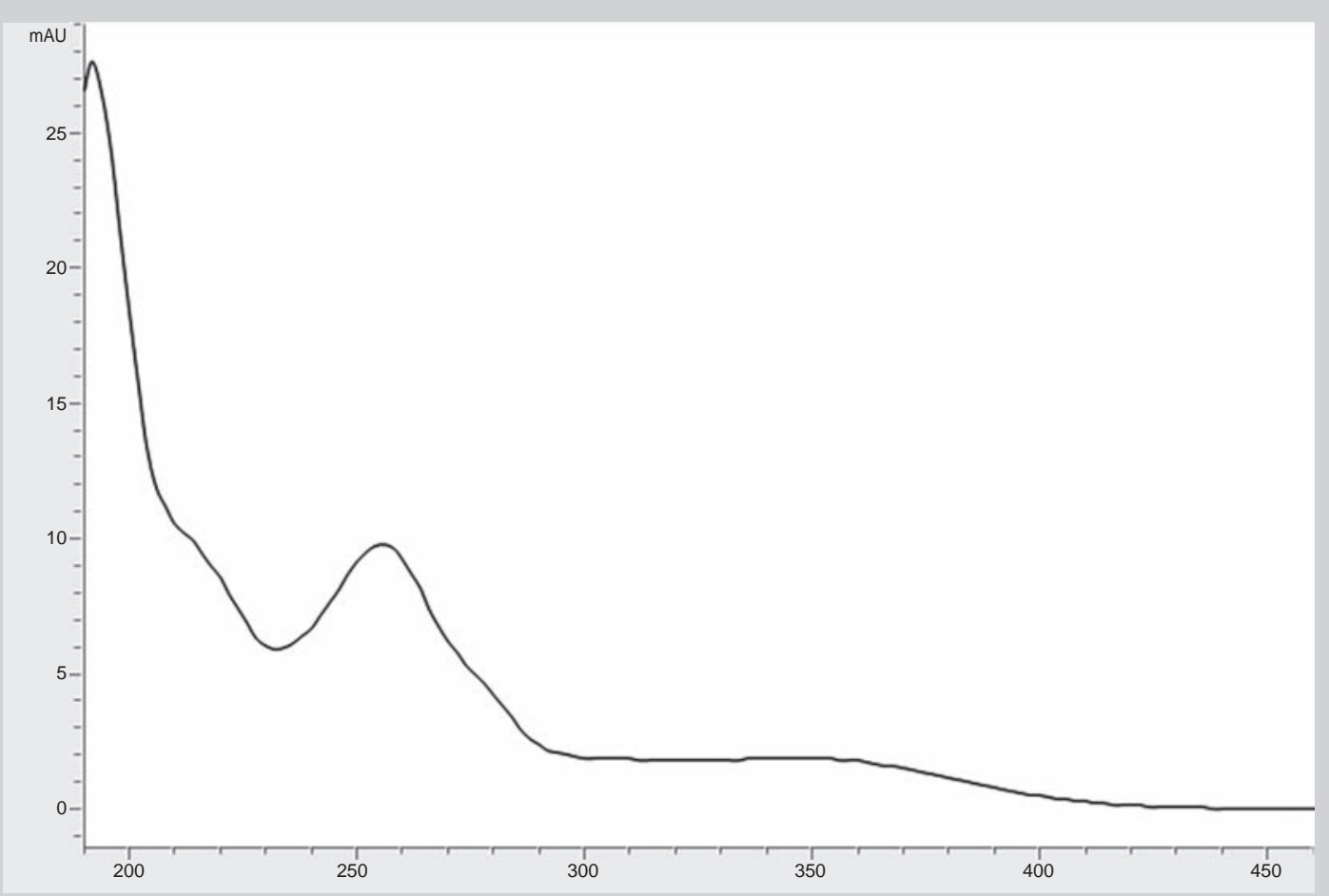

Fig. 8. UV spectra of 4-(2-methoxyphenyl)-5-(pyridine-4-yl)-2,4-dihydro-3H-1,2,4-triazole-3-thione.

Six different curves which show dependence of absolute value of retention factors differences $(|\Delta k|)$ for each compound from the acetonitrile in mobile phase was built at registration of the signal on diode-array detector (wavelength $254 \mathrm{~nm}$ ).

Maximal absolute values of retention factors differences $(|\Delta k|)$ were at $15 \%$ content of acetonitrile (Fig. 5). For problematic separation of 1-3 and 1-4 compounds absolute values of retention factors differences $(|\Delta k|)$ was same at $15-16 \%$.

Study of UV spectra of API and impurities needs to choose the analytic wavelength, which can be used for determination of appropriate compounds (Fig. 6-8).

The maximums of absorption values are $266 \mathrm{~nm}$ (compound 2), $254 \mathrm{~nm}$ (compound 3), $258 \mathrm{~nm}$ (compound 4).

The hydazide (0.694 min), carbothioamide (3.859 min), thione (5.566 $\mathrm{min}$ ) and some unidentified impurities were found on the chromatogram of model solution of the bulk drug with impurities addition at $272 \mathrm{~nm}$ (API concentration is $0.5 \mathrm{~g} / \mathrm{L}$, injection volume is $5 \mu \mathrm{L}$ ) (Fig. 9). The retention time of API was 4.919 min.

Validation of impurities determination method in bulk drug. Prediction of uncertainty of method.

Uncertainty calculation of preparation of the solution of standard samples:

- weighing of the standard sample of compounds 2, 3 or $4:(0.2 \mathrm{mg} / 25 \mathrm{mg}) \times 100=0.8 \%$;

- bringing the volume of the solution in volumetric flask with $100.0 \mathrm{~mL}$ capacity: $0.12 \%$;

- taking aliquot of solution by pipette with $1.00 \mathrm{~mL}$ capacity: $0.6 \%$;

- bringing the volume of solution in volumetric flask with capacity $100.0 \mathrm{~mL}: 0.12 \%$;
Uncertainty calculation of preparation the investigated solution:

- weighing of the of investigated sample:

$(0.2 \mathrm{mg} / 250 \mathrm{mg}) \times 100=0.08 \%$;

- bringing the value of the solution in volumetric flask with capacity $100.0 \mathrm{~mL}: 0.12 \%$.

- Total sample preparation uncertainty:

$$
\Delta_{S P}=\sqrt{0.8^{2}+0.12^{2}+0.6^{2}+0.12^{2}+0.08^{2}+0.12^{2}}=1.36 \%
$$

According to Ph. Ukr. (The Supplement 1 and 2) the uncertainty of sample preparation should be not significant, comparing with the maximum permissible method analysis uncertainty, $\Delta_{\mathrm{SP}} \leq 0.35 \times 5=1.6 \%$. Thus, the predicted value $\Delta_{\mathrm{SP}}$ complied with requirements of $\mathrm{Ph}$. Ukr. $(1.36 \%<1.6 \%)$.

Validation characteristics of the method. Validation of method was conducted according to $\mathrm{Ph}$. Ukr. requirements in variant of standard method by provided standardized procedure. The maximum of permissible uncertainty of analysis at quantitation of impurities was $5 \%$, at limited test was $16 \%$. For validation criteria calculation of the compound

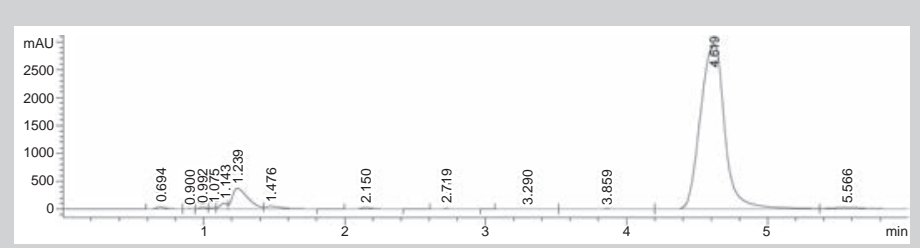

Fig. 9. Cromatogram of model solution of the bulk drug with compounds 2, 3, 4 addition at wavelength $272 \mathrm{~nm}$. 
Table 2. Metrological characteristics of linear dependence for the method for a compound $(2)(Y=b X+a)$

\begin{tabular}{llll}
\hline Parameter & Value & $\begin{array}{l}\text { The criteria } \\
\text { of acceptability } \\
\left(\Delta_{\mathrm{As}}=16 \%, \mathrm{~g}=9\right)\end{array}$ & Conclusion \\
\hline$b$ & 0.910 & - & - \\
$S_{\mathrm{b}}$ & 0.0344 & - & - \\
$a$ & 2.163 & $\leq 6.8$ & complied \\
$S_{\mathrm{a}}$ & 2.845 & - & - \\
$R S D_{0}$ & 3.733 & $\leq 8.4$ & complied \\
$R_{\mathrm{c}}$ & 0.995 & $\geq 0.9755$ & complied \\
\hline
\end{tabular}

Table 3. Metrological characteristics of linear dependence for the method for a compound (3) $(Y=b X+a)$

\begin{tabular}{llll}
\hline Parameter & Value & $\begin{array}{l}\text { The criteria } \\
\text { of acceptability } \\
\left(\boldsymbol{\Delta}_{\mathrm{As}}=\mathbf{5} \%, \mathbf{g}=\mathbf{9}\right)\end{array}$ & Conclusion \\
\hline$b$ & 1.005 & - & - \\
$S_{\mathrm{b}}$ & 0.00956 & - & - \\
$a$ & -0.739 & $\leq 2.1$ & complied \\
$S_{\mathrm{a}}$ & 0.731 & - & - \\
$R S D_{0}$ & 0.985 & $\leq 2.65$ & complied \\
$R_{\mathrm{c}}$ & 0.9997 & $\geq 0.9976$ & complied \\
\hline
\end{tabular}

Table 4. Metrological characteristics of linear dependence for the method for a compound $(4)(Y=b X+a)$

\begin{tabular}{llll}
\hline Parameter & Value & $\begin{array}{l}\text { The criteria } \\
\text { of acceptability } \\
\left(\boldsymbol{\Delta}_{\mathrm{As}}=5 \%, g=9\right)\end{array}$ & Conclusion \\
\hline$b$ & 1.008 & - & - \\
$S_{\mathrm{b}}$ & 0.01935 & - & - \\
$a$ & -0.9515 & $\leq 2.1$ & complied \\
$S_{\mathrm{a}}$ & 1.512 & - & - \\
$R S D_{0}$ & 2.023 & $\leq 2.65$ & complied \\
$R_{\mathrm{c}}$ & 0.9987 & $\geq 0.9976$ & Complied \\
\hline
\end{tabular}

(2) was selected $16 \%$, and at validation criteria calculation of the compound (3) and (4) was selected most stringent requirements $(5 \%)$, because results were complied with its requirements.

Linearity.

Metrological characteristics of linear dependence for using method range (25-125\%) from the nominal content of appropriate impurity are shown at tables 2-4. Linearity was complied with requirements of Ph. Ukr.

Selectivity.

Pick of API was fully separated with picks of compound 2, 3, 4 R $\geq 2.96$ (between picks of API and compound 3 ) and $\mathrm{R} \geq 2.65$ (between picks of the compound 4 and $A P I$ ).

Precision and accuracy.

The results of precision and accuracy determination of the method of quantitative determination of impurities in the bulk drug morpholinium 2-((4-(2-methoxyphenyl)-5pyridine-4-yl)-4H-1,2,4-triazole-3-yl)thio)acetate are shown at tables 5-7. Precision and accuracy were complied with requirements of $\mathrm{Ph}$. Ukr.

The use of method for quantitative determination of API in bulk drug

In the investigated series of bulk drug the impurity of carbothioamide (compound 3) was not detected. That is why we have conducted determination of compounds (2) and (4).The solution was chromatographed 5 times. Results are shown at table 8, 9

Received value of RSD did not exceed the calculated one, accordingly to $\mathrm{Ph}$. Ukr. requirements to $\mathrm{RSD} \%_{\max }$ for the maximal uncertainty $16 \%$ (compound 2 ) and $5 \%$ (compound 4 ) at all values $n$, beginning from $n=2$. Therefore, it is enough for alternate chromatography of the comparing and test solutions for each investigated sample of bulk drug [8]. The humidity of the bulk drug is identified on a loss of weight during the drying, it was $0.1 \%$.

As we can see, the reproducibility of results at determination of compound (4) was better than at determination of compound (2) (Table 10, 11).

Table 5. Precision and accuracy results of the method for a compound (2)

\begin{tabular}{|c|c|c|c|c|c|}
\hline Model solution & $\begin{array}{l}\text { The mass } \\
\text { of a sample (2), } \mathrm{g} \\
\left(m_{\mathrm{st}}=0.02422 \mathrm{~g}\right)\end{array}$ & $\begin{array}{l}\text { Added in } \% \text { to concentration } \\
\text { of standard solution, } X_{i}\end{array}$ & $\begin{array}{l}\text { Average pick area, } S_{\mathrm{i}} \\
\left(S_{\mathrm{st}}=98.61\right)\end{array}$ & $\begin{array}{l}\text { Found in } \% \text { to pick area } \\
\text { of standard solution, } Y_{\mathrm{i}}\end{array}$ & $Z_{i}=\frac{Y_{i}}{X_{i}} \times 100 \%$ \\
\hline 1 & 0.00659 & 27.21 & 25.08 & 25.43 & 93.47 \\
\hline 2 & 0.00689 & 28.45 & 30.44 & 30.87 & 108.5 \\
\hline 3 & 0.01279 & 52.81 & 51.77 & 52.50 & 99.42 \\
\hline 4 & 0.01245 & 51.40 & 49.72 & 50.42 & 98.09 \\
\hline 5 & 0.01835 & 75.76 & 66.49 & 67.42 & 80.90 \\
\hline 6 & 0.01849 & 76.34 & 66.78 & 67.72 & 88.71 \\
\hline 7 & 0.02509 & 103.59 & 95.13 & 96.47 & 93.13 \\
\hline 8 & 0.03139 & 129.60 & 124.5 & 126.31 & 97.42 \\
\hline 9 & 0.0303 & 125.10 & 110.8 & 112.35 & 89.82 \\
\hline \multicolumn{5}{|l|}{ Average, $\bar{Z} \%$} & 95.28 \\
\hline \multicolumn{5}{|c|}{ The relative standard deviation, $R S D_{z}, \%$} & 6.690 \\
\hline \multicolumn{5}{|c|}{ The relative confidence interval, $\Delta_{\mathrm{z}}=R S D_{\mathrm{z}} \times \mathrm{t}(95 \% ; \mathrm{n}-1)=R S D_{\mathrm{z}} \times 1.8595$} & 12.44 \\
\hline \multicolumn{5}{|c|}{ The criteria of acceptability for repeatability of results: $\Delta_{A s} \leq 16$} & complied \\
\hline \multicolumn{5}{|c|}{ Systematic error, $\delta=|100-\bar{z}|$} & 4.716 \\
\hline \multicolumn{5}{|c|}{$\begin{array}{l}\text { Insignificance criterion of systematic error: } \\
\text { 1) } \delta \leq \Delta_{\mathrm{Z}} / 3=12.44 / 3=4.15 \\
\text { 2) } \delta \leq 0.32 \times 16=5.12\end{array}$} & $\begin{array}{l}\text { not complied } \\
\text { complied }\end{array}$ \\
\hline \multicolumn{5}{|c|}{ General conclusion about method } & correct \\
\hline
\end{tabular}


Table 6. Precision and accuracy results of the method for a compound (3)

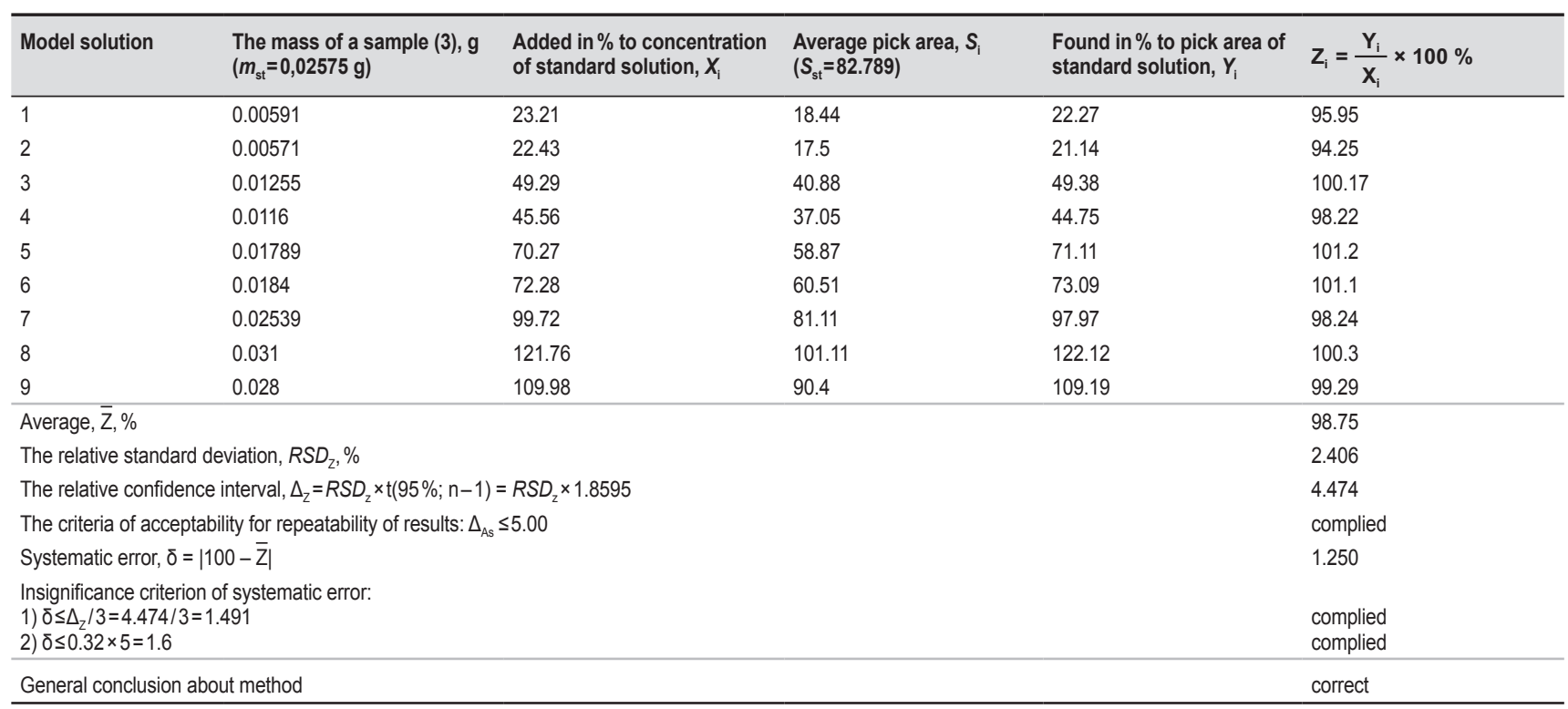

Table 7. Precision and accuracy results of the method for a compound (4)

\begin{tabular}{|c|c|c|c|c|c|}
\hline $\begin{array}{l}\text { Model } \\
\text { solution }\end{array}$ & $\begin{array}{l}\text { The mass of a sample }(4), \mathrm{g} \\
\left(\mathrm{m}_{\mathrm{st}}=0.02460 \mathrm{~g}\right)\end{array}$ & $\begin{array}{l}\text { Added in } \% \text { to concentration } \\
\text { of standard solution, } X_{i}\end{array}$ & $\begin{array}{l}\text { Average pick area, } S_{i} \\
\left(S_{\mathrm{st}}=117.937\right)\end{array}$ & $\begin{array}{l}\text { Found in } \% \text { to pick area of } \\
\text { standard solution, } Y_{\mathrm{i}}\end{array}$ & $Z_{i}=\frac{Y_{i}}{X_{i}} \times 100 \%$ \\
\hline 1 & 0.00638 & 25.14 & 30.48 & 25.84 & 102.81 \\
\hline 2 & 0.00585 & 23.05 & 26.48 & 22.45 & 97.41 \\
\hline 3 & 0.0129 & 50.83 & 59.84 & 50.74 & 99.83 \\
\hline 4 & 0.01245 & 49.05 & 55.02 & 46.65 & 95.10 \\
\hline 5 & 0.01665 & 65.60 & 77.41 & 65.64 & 100.05 \\
\hline 7 & 0.02312 & 91.1 & 105.15 & 89.16 & 97.87 \\
\hline 8 & 0.03155 & 124.31 & 151.05 & 128.1 & 103.03 \\
\hline 9 & 0.03009 & 118.56 & 136.98 & 116.1 & 97.97 \\
\hline \multicolumn{5}{|c|}{ Average, $\bar{Z}, \%$} & 99.26 \\
\hline \multicolumn{5}{|c|}{ The relative standard deviation, $R S D_{Z}, \%$} & 2.570 \\
\hline \multicolumn{5}{|c|}{ The relative confidence interval, $\Delta_{z}=R_{2} \times t(95 \% ; n-1)=R_{z} D_{z} \times 1.8595$} & 4.779 \\
\hline \multicolumn{5}{|c|}{ The criteria of acceptability for repeatability of results: $\Delta_{A s} \leq 5.00$} & complied \\
\hline \multicolumn{5}{|c|}{$\begin{array}{l}\text { Insignificance criterion of systematic error } \\
\text { 1) } \delta \leq \Delta_{z} / 3=4.779 / 3=1.593 \\
\text { 2) } \delta \leq 0.32 \times 5=1.6\end{array}$} & $\begin{array}{l}\text { complied } \\
\text { complied }\end{array}$ \\
\hline \multicolumn{5}{|c|}{ General conclusion about method } & correct \\
\hline
\end{tabular}

Table 8. Results of the system suitability test on RSD in bulk drug (2)

\begin{tabular}{lllll}
\hline Chromatogram & S $_{\text {st }}$ & Mean st $_{\text {st }}$ & RSD $\%$ & RSD ${ }_{\text {max }}$ \\
\hline 1 & 97.28 & - & - & - \\
2 & 97.44 & 97.36 & 0.1232 & 2.534 \\
3 & 97.94 & 97.55 & 0.3562 & 6.710 \\
4 & 98.19 & 97.71 & 0.4364 & 9.613 \\
5 & 97.68 & 97.70 & 0.3782 & 11.86 \\
\hline
\end{tabular}

Table 9. Results of the system suitability test by RSD in bulk drug (4)

\begin{tabular}{lllll}
\hline Chromatogram & S $_{\text {st }}$ & Mean st $_{\text {st }}$ & RSD \% & RSD \% ${ }_{\text {max }}$ \\
\hline 1 & 117.53 & - & - & - \\
2 & 117.02 & 117.28 & 0.3050 & 0.7918 \\
3 & 117.26 & 117.27 & 0.2158 & 2.097 \\
4 & 117.96 & 117.44 & 0.3417 & 3.004 \\
5 & 118.15 & 117.58 & 0.3990 & 3.708 \\
\hline
\end{tabular}


Table 10. The results of quantitative determination of compound (2) in a bulk drug

\begin{tabular}{|c|c|c|c|c|c|}
\hline \multirow{2}{*}{$\begin{array}{l}\text { Sample } \\
1\end{array}$} & \multirow{2}{*}{$\begin{array}{l}\text { The mass } \\
\text { of a sample, } \mathrm{g}\end{array}$} & \multicolumn{2}{|c|}{ Pick area } & \multirow{2}{*}{$\begin{array}{l}\begin{array}{l}\text { Found (2) } \\
\text { in } \%\end{array} \\
0.1256\end{array}$} & \multirow{2}{*}{$\begin{array}{l}\text { Metrological characteristics } \\
\mathrm{n}-1=5, \mathrm{P}=0.95 \\
\overline{\mathrm{X}}=0.1365\end{array}$} \\
\hline & & 122.9 & 125.3 & & \\
\hline & & 127.7 & & & $S=0.00868$ \\
\hline \multirow[t]{2}{*}{2} & 0.24898 & 146.1 & 146.4 & 0.1478 & $S_{r}=6.361 \%$ \\
\hline & & 146.6 & & & $\Delta \overline{\mathrm{X}}=0.009107$ \\
\hline \multirow[t]{2}{*}{3} & 0.25028 & 129.1 & 128.9 & 0.1295 & $\varepsilon=6.674 \%$ \\
\hline & & 128.6 & & & \\
\hline \multirow[t]{2}{*}{4} & 0.27094 & 157.0 & 156.5 & 0.1453 & \\
\hline & & 156.0 & & & \\
\hline \multirow[t]{2}{*}{5} & 0.23028 & 125.1 & 123.5 & 0.1349 & \\
\hline & & 121.9 & & & \\
\hline \multirow[t]{2}{*}{6} & 0.23016 & 124.1 & 124.1 & 0.1356 & \\
\hline & & 124.1 & & & \\
\hline $\begin{array}{l}\text { Standard } \\
\text { sample }\end{array}$ & 0.02446 & 97.36 & & & \\
\hline
\end{tabular}

Table 11. The results of quantitative determination of compound (4) in a bulk drug

\begin{tabular}{|c|c|c|c|c|c|}
\hline \multirow{2}{*}{$\begin{array}{l}\text { Sample } \\
1\end{array}$} & \multirow{2}{*}{$\begin{array}{l}\text { The mass } \\
\text { of a sample, } \mathbf{g}\end{array}$} & \multicolumn{2}{|c|}{ Pick area } & \multirow{2}{*}{$\begin{array}{l}\begin{array}{l}\text { Found (4) } \\
\text { in } \%\end{array} \\
0.3357\end{array}$} & \multirow{2}{*}{$\begin{array}{l}\text { Metrological characteristics } \\
\mathrm{n}-1=5, \mathrm{P}=0.95 \\
\overline{\mathrm{X}}=1.019\end{array}$} \\
\hline & & 388.1 & 388.7 & & \\
\hline & & 389.3 & & & $S=0.02657$ \\
\hline \multirow[t]{2}{*}{2} & 0.24898 & 395.9 & 399.3 & 0.3474 & $S_{r}=2.607 \%$ \\
\hline & & 402.7 & & & $\Delta \bar{X}=0.009439$ \\
\hline \multirow[t]{2}{*}{3} & 0.25028 & 401.2 & 401.2 & 0.3473 & $\varepsilon=2.735 \%$ \\
\hline & & 401.2 & & & \\
\hline \multirow[t]{2}{*}{4} & 0.27094 & 448.6 & 450.8 & 0.3604 & \\
\hline & & 453 & & & \\
\hline \multirow[t]{2}{*}{5} & 0.23028 & 371.5 & 358.4 & 0.3372 & \\
\hline & & 345.3 & & & \\
\hline \multirow[t]{2}{*}{6} & 0.23016 & 359.9 & 363.55 & 0.3422 & \\
\hline & & 367.2 & & & \\
\hline $\begin{array}{l}\text { Standard } \\
\text { sample }\end{array}$ & 0.02538 & 117.27 & & & \\
\hline
\end{tabular}

\section{Conclusions}

Chromatography separation of impurities and morpholinium 2-((4-(2-methoxyphenyl)-5-(pyridine-4-yl)-4H-1,2,4-triazole-3-yl)thio)acetate was done. A method of determination of those impurities was proposed. A method was complied with linearity criteria, specificity, precision and accuracy. The results of impurity determination in bulk drug indicated, that method can be used for the quality control of bulk drug of morpholinium 2-((4-(2-methoxyphenyl)-5-pyridine-4-yl)-4H1,2,4-triazole-3-yl)thio)acetate.

\section{Acknowledgements}

We acknowledge complete support of the Zaporizhzhia State Medical University. We thank rector of Zaporizhzhia State Medical University Prof. Yu. M. Kolesnyk for his help and support.

\section{References}

[1] Kaplaushenko, A. H. (2012) Syntez, budova i biolohichna aktyvnist pokhidnykh 4-mono-ta 4,5-dyzamishchenykh 1,2,4-triazol-3-tionu (Dis... dokt. med. nauk). [Synthesis, structure and biological activity of 4-mono- and 4,5-disubstituted 1,2,4-triazoles-3-thione. Dr. med. sci. diss.]. Zaporizhzhia. [in Ukrainian].

[2] Kaplaushenko, A. H., Panasenko, O. I., Knysh, Ye. H., Vasiuk, S. O., \& Tarkhanova, O. O. (2009). Rozrobka metodiv yakisnoho ta kilkisnoho vyznachennia morfolinii 2-(5-(4-pirydyl)-4-(2-metoksyfenil)-1,2,4- tryazol-3-iltio) atsetatu [Development of methods for qualitative and quantitative determination morpholino 2-(5-(4-pyridyl)-4-(2-methoxyphenyl)-1,2,4-triazole-3-ylthio) acetate]. Zaporozhye medical journal, 1, 79-81. [in Ukrainian]

[3] (2013). European Pharmacopoeia. Strasbourg, France: Council of Europe.

[4] Derzhavna Farmakopeia Ukrainy. Dopovnennia 1. (2004) [The State Pharmacopoeia of Ukraine. Vol. 1]. Kharkiv: RIREH. [in Ukrainian].

[5] Varynskyi, B. O. (2015) Doslidzhennia kharakterystyk utrymuvannia riadu hidrazydiv karbonovykh kyslot i hidrazynokarbotioamidiv, vykhidnykh rechovyn pry syntezi substantsii dlia vyhotovlennia likarskykh zasobiv metodom VERKh-UF-ESI-MS [Study retention characteristics of series hydrazides of carboxylic acids and hydrazynocabothioamids, starting materials in the synthesis of bulk drugs for manufacturing of the pharmaceutical preparations by HPLC-UV-ESI-MS]. Problemy viiskovoi okhorony zdorovia. Zbirnyk naukovykh prats Ukrainskoi viiskovomedychnoi akademii, 43, 320-330. [in Ukrainian].

[6] Varynskyi, B. O., Knysh, Ye. G., Parchenko, V. V., Panasenko, O. I., \& Kaplaushenko, A. G. (2015) Vyvchennya zakonomirnostey utrymuvannya potentsiynykh llikars'kykh substantsiy ryadu 1,2,4-triazol-3-iltioatsetatnykh kyslot ta yikh soley metodom VERKh/DMD-MS [The study of retention regularities for the potential drug substances of 1,2,4-triazol-3-ylthioacetic acids and their salts series by the method of HPLC/DAD-MS] Zhurnal orhanichnoi ta farmatsevtychnoi khimii, 13, 4(52), 68-72. [in Ukrainian].

[7] Varynskyi, B. O. (2016) Vyvchennia metodom VERKh-DMD-MS zakonomirnostei utrymuvannia riadu 1,2,4-triazol-3-tioniv - napivproduktiv v syntezi aktyvnykh farmatsevtychnykh inhrediientiv [Optimization of the detection conditions for the series of 1,2,4-triazole-3-thiones for FIA-ESI-MS and HPLC-ESI-MS]. Farmakom, 1, 32-40. [in Ukrainian].

[8] Derzhavna Farmakopeia Ukrainy (2001) [The State Pharmacopoeia of Ukraine]. Kharkiv: RIREH. [in Ukrainian].

\section{Information about authors:}

Varynskyi B. 0., PhD, Associate Professor,

The Department of Physical and Colloidal Chemistry, Zaporizhzhia State Medical University, Ukraine.

Kaplaushenko A. G., Dr.hab., Associate Professor,

Head of The Department of Physical and Colloidal Chemistry,

Zaporizhzhia State Medical University, Ukraine.

\section{Відомості про авторів:}

Варинський Б. О., канд. фарм. наук, доцент каф. фізколоїдної хімії, Запорізький державний медичний університет, Україна. Каплаушенко А. Г., А-р фарм. наук, Аоцент, зав. каф. фізколоїдної хімії, Запорізький Аержавний медичний університет, Україна.

\section{Сведения об авторах:}

Варинский Б. А., канА. фарм. наук, Аоцент каф. физкомоияной химии, Запорожский госуАарственный медицинский университет, Украина.

Каплаушенко А. Г., А-р фарм. наук, Аоцент,

зав. каф. физкоммоиАной химии, Запорожский государственный медицинский университет, Украина.

Конфмікт інтересів: віАсутній.

Conflicts of Interest: authors have no conflict of interest to declare.

Надійшло Ао редакції / Received: 07.03.2017

Після Аоопрацювання / Revised: 29.03.2017

Прийнято Ао Аруку / Accepted: 03.04.2017 